\title{
Penerapan Model Pembelajaran Inkuiri Terbimbing Untuk Mendukung Kemampuan Literasi Sains Siswa Pada Materi Sistem Koloid
}

\author{
Isni Fitri ${ }^{1}$, Yuni Fatisa ${ }^{2}$ \\ ${ }^{1,2}$ Jurusan Pendidikan Kimia, Universitas Islam Negeri Sultan Syarif Kasim Riau \\ e-mail: \\ 1 isnifitri@gmail.com \\ 2YYunifatisa@yahoo.co.id
}

\begin{abstract}
.
Scientific literacy was an important thing that should be mastered by students to understand living environment, bealth, economics, and other problems that were encountered by modern society relying heavily on technology, advancement, and development of science. This research aimed at knowing student scientific literacy ability through the implementation of Guided Inquiry learning model on Colloid System lesson at the eleventh grade of State Senior High School 5 Pekanbaru. This research was Pre-experiment with one-group pretest-posttest design. The techniques of collecting the data were scientific literacy test in the form of multiple choice, observation sheet, and documentation. The achievement results of student scientific literacy of each indicator showed that implementing the appropriate knowledge was $71.67 \%$, identifying was $76 \%$, predicting was $75 \%$, submitting clear bypothesis was $76.25 \%$, suggesting the ways to investigate scientific question was $58.75 \%$, and drawing the right conclusion was $76.25 \%$. The results of student scientific literacy ability showed that the posttest mean score was $72.32 \%$ on good category.
\end{abstract}

Keywords: scientific literacy, guided inquiry, colloid system.

\begin{abstract}
ABSTRAK.
Literasi ilmiah adalah hal penting yang harus dikuasai oleh siswa untuk memahami lingkungan hidup, kesehatan, ekonomi, dan masalah lain yang dihadapi oleh masyarakat modern yang sangat bergantung pada teknologi, kemajuan, dan pengembangan ilmu pengetahuan. Penelitian ini bertujuan untuk mengetahui kemampuan literasi sains siswa melalui penerapan model pembelajaran Guided Inquiry pada pembelajaran Sistem Koloid di kelas XI SMA Negeri 5 Pekanbaru. Penelitian ini adalah Pra-eksperimen dengan desain satu kelompok pretest-posttest. Teknik pengumpulan data adalah tes literasi ilmiah dalam bentuk pilihan ganda, lembar observasi, dan dokumentasi. Hasil pencapaian literasi sains siswa masing-masing indikator menunjukkan bahwa menerapkan pengetahuan yang sesuai adalah $71,67 \%$, mengidentifikasi $76 \%$, memprediksi $75 \%$, mengajukan hipotesis jelas adalah $76,25 \%$, menunjukkan cara untuk menyelidiki pertanyaan ilmiah adalah 58,75\%, dan menggambar kesimpulan yang tepat adalah 76,25\%. Hasil kemampuan literasi sains siswa menunjukkan bahwa skor rata-rata postes adalah $72,32 \%$ pada kategori baik.
\end{abstract}

Kata kunci: literasi ilmiah, inkuiri terbimbing, sistem koloid. 


\section{PENDAHULUAN}

Literasi sains merupakan hal yang penting untuk dikuasai oleh siswa dalam kaitannya dengan cara siswa dapat memahami lingkungan hidup, kesehatan, ekonomi, dan masalah-masalah lain yang dihadapi oleh masyarakat modern yang sangat bergantung pada teknologi dan kemajuan, serta perkembangan ilmu pengetahuan (U. Toharudin, 2011).

Literasi sains (literasi ilmiah) yaitu suatu ilmu pengetahuan dan pemahaman mengenai konsep dan proses sains yang memungkinkan seseorang untuk membuat suatu keputusan dengan pengetahuan yang dimilikinya, serta turut terlibat dalam hal kenegaraan, budaya dan pertumbuhan ekonomi (F. Huryah, R. Sumarmin, dan J. Effendi, 2017). Rendahnya tingkat literasi sains siswa menjadi salah satu permasalahan pendidikan di Indonesia. Hal ini didukung oleh data pencapaian literasi sains siswa Indonesia dalam asesmen literasi sains PISA. Selama tiga kali mengikuti asesmen literasi sains PISA tahun 2006, 2009, dan 2012, rata-rata pencapaian skor literasi sains siswa masih dalam rentang skor 382-395, jauh di bawah skor rata-rata pencapaian literasi sains PISA yaitu 500 (P. Rohmi, 2017). Rendahnya kemampuan siswa ini dikarenakan pembelajaran sains di kelas belum memfasilitasi siswa dalam melatihkan literasi sains (W I Novili, S Utari, D Saepuzaman, dan S Karim, 2017). Proses pembelajaran yang dilaksanakan lebih banyak pada transfer pengetahuan dengan metode ceramah di dalam kelas dan latihan-latihan soal sebagai penguat konsep (Mohamad Yafuz Bil Amri, 2017)

Berdasarkan hasil wawancara peneliti dengan guru kimia kelas XI di SMA Negeri 5 Pekanbaru menyatakan bahwa siswa kurang mampu dalam mengaitkan pengetahuan sains yang dipelajarinya dengan fenomena yang terjadi di dalam kehidupan sehari-hari khususnya yang berkaitan dengan kimia. Hal ini dikarenakan siswa-siswa cenderung menghafalkan konsep dan teori tanpa ada pemahaman yang mendalam dari suatu materi kimia tersebut.

Guru memang menggunakan metode dalam menjelaskan materi sistem koloid antara lain dengan metode diskusi yang melibatkan interaksi dan peran siswa dalam proses pembelajaran namun metode ini membatasi siswa dalam mengembangkan materi dimana hanya pada materi yang ada pada bahan ajar. Oleh karena itu, dibutuhkan suatu model pembelajaran yang dapat membantu siswa dalam proses pembelajaran. Salah satu model pembelajaran yang dapat digunakan adalah model pembelajaran inkuiri terbimbing.

Pembelajaran inkuiri terbimbing, yaitu suatu model pembelajaran inkuiri yang dalam pelaksanaannya guru menyediakan bimbingan atau petunjuk cukup luas kepada peserta didik. Inkuiri menyediakan peserta didik aneka ragam pengalaman konkret dan pembelajaran aktif yang mendorong, memberikan ruang dan peluang kepada peserta didik untuk mengambil inisiatif dalam mengembangkan keterampilan pemecahan masalah, pengambilan keputusan, dan penelitian sehingga memungkinkan mereka menjadi pembelajar sepanjang hayat (M. Fathurrohman, 2015).

Dalam pembelajaran inkuiri siswa diajak untuk berpikir sehingga dapat membangun sikap produktif, analitis, dan kritis. Dengan berpikir maka peserta didik akan mendapatkan pengalaman belajar yang bermakna. Pengalaman belajar yang didapatkan oleh peserta didik ini akan memberikan makna bagi kehidupan sehari-hari siswa nantinya (A. Rakhmawan, A. Setiabudi, dan A. Mudzakir, 2015). Keaktifan atau proses kerja inkuiri dalam mengikuti proses pembelajaran diperlukan agar pengetahuan yang diperoleh peserta didik dapat lebih bertahan lama (Y. Yuliati, 2017).

Beberapa kajian menyatakan bahwa model pembelajaran inkuiri terbimbing dapat mempengaruhi literasi sains siswa. Salah satu diantaranya adalah penelitian dari Pratika dan Muchlis menyimpulkan bahwa model pembelajaran inkuiri terbimbing dapat melatihkan kemampuan literasi sains siswa (V. D. I. Pratika dan Muchlis, 2016)

Materi yang digunakan dalam penelitian ini adalah materi sistem koloid, hal ini dikarenakan materi koloid mempunyai peranan penting dalam kelangsungan hidup manusia, baik menyangkut 
lingkungan maupun kehidupan sehari-hari sehingga materi ini tentu berkaitan dengan makna literasi sains itu sendiri. Pembelajaran sistem koloid mudah mendorong siswa membuat hubungan antara pengetahuan yang dimilikinya dengan penerapannya di kehidupan sehari-hari (N.Chairisa, A. Sholahuddin, dan Leny, 2016)

Berdasarkan uraian tersebut, maka peneliti tertarik untuk melakukan penelitian dengan judul "Penerapan Model Pembelajaran Inkuiri Terbimbing untuk Mendukung Kemampuan Literasi Sains Siswa pada Materi Sistem Koloid".

\section{METODOLOGI}

Metode yang digunakan dalam penelitian ini adalah pre-experimental. Metode ini merupakan metode eksperimen, namun tidak menggunakan kelompok kontrol ataupun kelompok pembanding. Desain penelitian yang digunakan adalah one group pretest-posttest. Desain one group pretest-posttest digambarkan sebagai berikut (Sugiyono, 2017):

\section{$\mathbf{O}_{1} \mathrm{X} \mathrm{O}_{2}$}

Keterangan:

\section{Gambar 1. One group pretest-posttest design}

$\mathrm{O}_{1} \quad$ : Pretest

$\mathrm{O}_{2} \quad$ : Posttest

$\mathrm{X} \quad$ : Perlakuan (Inkuiri terbimbing)

Penelitian ini sampel diambil hanya satu kelas. Teknik yang digunakan dalam pengambilan sampel ini adalah teknik purposive sampling, yaitu teknik sampling yang digunakan oleh peneliti jika peneliti mempunyai pertimbangan-pertimbangan tertentu di dalam pengambilan sampelnya (Suharsimi Arikunto, 2009). Pertimbangan peneliti dalam penelitian ini dikarenakan menggunakan model pembelajaran inkuiri terbimbing maka dipilih kelas yang heterogen dan kelas yang mudah dikondisikan.

Pengumpulan data yang digunakan dalam penelitian ini adalah tes kemampuan literasi sains, lembar observasi, dan dokumentasi. Tes kemampuan literasi sains yang digunakan adalah soal pilihan ganda pada pokok bahasan sistem koloid. Soal yang digunakan adalah soal yang sudah divalidasi oleh ahli, selain itu proses validasi instrumen soal dilakukan dengan uji coba soal kemudian dianalisis menggunakan program Anates V4 untuk mengetahui validitas, reliabilitas, tingkat kesukaran dan daya beda soal.

Untuk mengetahui pencapaian kemampuan literasi sains siswa dalam setiap indikator, maka peneliti melakukan perhitungan persentase pencapaian kemampuan literasi sains siswa dengan menggunakan persamaan (1).

$$
\mathrm{N}=\frac{k}{N k} \times 100 \%
$$

\section{Keterangan:}

$$
\begin{array}{ll}
\mathrm{N} & : \text { Jumlah persentase skor } \\
k & : \text { Jumlah skor perolehan } \\
\text { Nk } & \text { : Jumlah skor maksimal (Azimi, A. 2017) }
\end{array}
$$


Berdasarkan hasil persentase yang diperoleh kemudian ditafsirkan ke dalam kriteria interpretasi skor sebagai berikut:

Tabel 1. Kriteria interpretasi skor (Riduwan, 2010)

\begin{tabular}{cc}
\hline Skor Persentase & Kriteria Interpretasi \\
\hline $0 \%-19,99 \%$ & Sangat kurang baik \\
\hline $20 \%-39,99 \%$ & Kurang baik \\
\hline $40 \%-59,99 \%$ & Cukup \\
\hline $60 \%-79,99 \%$ & Baik \\
\hline $80 \%-100 \%$ & Sangat baik \\
\hline
\end{tabular}

\section{TEMUAN DAN PEMBAHASAN}

\section{Data hasil pretest kemampuan literasi sains siswa.}

Kemampuan literasi sains siswa diperoleh dari lembar penilaian kemampuan literasi sains siswa berupa soal tes yang dikerjakan secara individu. Tes ini berupa soal pilihan ganda sebanyak 20 soal.

Tes pretest diberikan bertujuan untuk memperoleh hasil awal kemampuan literasi sains siswa sebelum proses pembelajaran. Pada tabel 2. disajikan rekapitulasi hasil pretest kemampuan literasi sains siswa.

Tabel 2. Rekapitulasi hasil pretest kemampuan literasi sains siswa

\begin{tabular}{clcc}
\hline No & \multicolumn{1}{c}{ Indikator Literasi Sains } & $\begin{array}{c}\text { Persentase } \\
(\boldsymbol{\%})\end{array}$ & Kategori \\
\hline 1 & Menerapkan pengetahuan yang sesuai & 23,33 & Kurang Baik \\
\hline 2 & Mengidentifikasi & 26,5 & Kurang Baik \\
\hline 3 & Membuat prediksi yang tepat & 25 & Kurang Baik \\
\hline 4 & Mengajukan hipotesis yang jelas & 23,75 & Kurang Baik \\
\hline 5 & $\begin{array}{l}\text { Mengusulkan cara untuk menyelidiki } \\
\text { pertanyaan ilmiah }\end{array}$ & 22,5 & Kurang Baik \\
\hline 6 & Menarik kesimpulan yang tepat & 22,5 & Kurang Baik \\
\hline & $\quad$ Rata-rata & 23,93 & Kurang Baik \\
\hline
\end{tabular}

Berdasarkan tabel 2 menunjukkan bahwa hasil rata-rata pretest kemampuan literasi sains siswa adalah sebesar 23,93\% yang berada dalam kategori kurang baik.

\section{Data hasil posttest kemampuan literasi sains siswa}

Tes posttest bertujuan untuk memperoleh hasil literasi sains siswa setelah diterapkan model pembelajaran inkuiri terbimbing. Rekapitulasi hasil posttest kemampuan literasi sains siswa disajikan pada tabel 3. 
Tabel 3. Rekapitulasi hasil posttest kemampuan literasi sains siswa

\begin{tabular}{clcc}
\hline No. & \multicolumn{1}{c}{ Indikator Literasi Sains } & $\begin{array}{c}\text { Persentase } \\
(\boldsymbol{\%})\end{array}$ & Kategori \\
\hline 1 & Menerapkan pengetahuan yang sesuai & 71,67 & Baik \\
\hline 2 & Mengidentifikasi & 76 & Baik \\
\hline 3 & Membuat prediksi yang tepat & 75 & Baik \\
\hline 4 & Mengajukan hipotesis yang jelas & 76,25 & Baik \\
\hline 5 & $\begin{array}{l}\text { Mengusulkan cara untuk menyelidiki } \\
\text { pertanyaan ilmiah }\end{array}$ & 58,75 & Cukup \\
\hline 6 & Menarik kesimpulan yang tepat & 76,25 & Baik \\
\hline & $\quad$ Rata-rata & 72,32 & Baik \\
\hline
\end{tabular}

Berdasarkan tabel 3 menunjukkan bahwa hasil rata-rata posttest kemampuan literasi sains siswa adalah $72,32 \%$ yang berada dalam kategori baik.

\section{Pelaksanaan pembelajaran inkuiri terbimbing}

Pembelajaran inkuiri terbimbing terdiri dari 6 tahapan, yaitu menyajikan pertanyaan atau masalah, membuat hipotesis, merancang percobaan, melakukan percobaan, mengumpulkan dan menganalisis data, dan membuat kesimpulan.

Tahap pertama, menyajikan pertanyaan atau masalah. Pada pelaksanaan pembelajaran di kelas sebelumnya guru mengkondisikan siswa terlebih dahulu untuk duduk sesuai dengan kelompoknya masing-masing. Selanjutnya siswa diberikan suatu fenomena yang berhubungan dengan materi pembelajaran, yaitu dalam kehidupan sehari-hari kita sering menemui suatu campuran, contohnya saja campuran air dengan gula, campuran air dengan susu, dan campuran air dengan kopi. Kemudian guru memberikan pertanyaan untuk memancing pemikiran siswa, yaitu apa yang kalian ketahui dari ketiga campuran tersebut.

Setelah melakukan tanya jawab dengan siswa guru membimbing siswa dalam mengidentifikasi masalah atau berupa pertanyaan seputar fenomena yang diberikan. Pada tahap ini kemampuan literasi sains yang didukung yaitu kemampuan mengidentifikasi.

Tahap kedua, membuat hipotesis. Dalam membuat hipotesis, siswa diberi kesempatan untuk menuangkan pendapatnya berdasarkan pengetahuan mereka sendiri. Banyak siswa dari tiaptiap kelompok yang bertanya atau meminta pendapat dari guru tentang hipotesis yang mereka tulis. Hal ini dikarenakan siswa kurang percaya diri dengan hipotesis yang mereka tulis.

Pada tahap ini kemampuan literasi sains yang didukung yaitu kemampuan menerapkan pengetahuan yang sesuai, membuat prediksi dan mengajukan hipotesis. Dalam membuat hipotesis siswa membuat prediksi atau memperkirakan kemungkinan jawaban dari suatu permasalahan yang dikaji, dan pada tahap membuat hipotesis ini siswa menerapkan pengetahuan yang sesuai. Hal ini sejalan dengan pendapat Sanjaya bahwasanya perkiraan sebagai hipotesis bukan sembarang perkiraan, tetapi harus memiliki landasan berpikir yang kokoh, sehingga hipotesis yang dimunculkan itu bersifat rasional dan logis (W. Sanjaya, 2007). 
Tahap ketiga, merancang percobaan. Sebelum melakukan percobaan siswa terlebih dahulu membuat rancangan percobaan. Siswa membuat rancangan percobaan melalui kegiatan diskusi dengan anggota kelompoknya masing-masing dan menuliskannya di lembar kerja yang disediakan. Kegiatan diskusi kelompok akan terjadi interaksi antar anggota kelompok seperti saling bertukar pendapat dan berbagi pengetahuan. Hal ini sejalan dengan pendapat Multhau dan Todd dalam El Islami salah satu diantara karakteristik dari inkuiri terbimbing adalah siswa belajar melalui interaksi sosial (R. A. Z. E. Islami, 2016).

Pada tahap merancang percobaan siswa diberikan langkah percobaan secara acak kemudian siswa mengurutkan langkah-langkah percobaan tersebut dengan bimbingan guru. Pada tahap ini kemampuan literasi sains yang didukung yaitu kemampuan mengusulkan cara untuk menyelidiki pertanyaan ilmiah. Dengan langkah percobaan yang diberikan secara acak siswa dapat mengusulkan cara dalam mengurutkan langkah-langkah percobaan dengan benar.

Tahap keempat, yaitu melakukan percobaan. Kegiatan melakukan percobaan ini dilakukan untuk memperoleh informasi. Dalam melakukan percobaan memberikan kesempatan bagi siswa untuk memanfaatkan panca indera semaksimal mungkin untuk mengamati fenomena yang terjadi. Kegiatan eksperimen atau percobaan siswa mendapatkan pengalaman nyata dengan ikut berperan aktif dalam kegiatan pembelajaran. Hal ini sesuai dengan pendapat Fathurrohman bahwasanya inkuiri menyediakan peserta didik aneka ragam pengalaman konkret dan pembelajaran aktif yang mendorong, memberikan ruang, dan peluang kepada peserta didik untuk mengambil inisiatif dalam mengembangkan keterampilan pemecahan masalah, pengambilan keputusan, dan penelitian sehingga memungkinkan mereka menjadi pembelajar sepanjang hayat (M. Fathurrohman, 2015). Saat melakukan percobaan, guru membimbing siswa dalam melakukan percobaan.

Tahap kelima, mengumpulkan dan menganalisis data. Pada tahap mengumpulkan data siswa mencatat hasil percobaan yang dilakukan di dalam lembar kerja yang disediakan dan juga mencari referensi dari buku-buku atau bisa juga dari dengan mencari literatur dari internet, kemudian dilanjutkan dengan menganalisis data hasil percobaan. Siswa berdiskusi dalam kelompoknya untuk menjawab pertanyaan yang terdapat di dalam lembar kerja yang disediakan. Pada kegiatan ini siswa dibimbing oleh guru. Analisis data melatih siswa untuk berpikir, dan melatih kemampuan menemukan informasi. Hal ini didukung oleh penelitian R. Choerunnisa, S. Wardani, dan S. S. Sumarti, (2017). bahwasanya belajar dengan model pembelajaran inkuiri terbimbing peserta didik belajar memecahkan masalah secara mandiri dan memiliki keterampilan berpikir kritis karena peserta didik harus selalu menganalisis dan menangani informasi.

Setelah siswa melakukan pengumpulan dan analisis data guru memberikan kesempatan kepada siswa untuk mempresentasikan hasil kerja kelompoknya kepada teman-teman lainnya, akan tetapi tidak semua kelompok yang bisa tampil untuk mempresentasikan hasil kerja kelompoknya dikarenakan keterbatasan waktu. Dalam hal ini sesuai dengan pendapat Sanjaya (2007) tentang kelemahan dari pembelajaran inkuiri yaitu kadang-kadang dalam mengimplementasikannya, memerlukan waktu yang panjang sehingga guru sulit menyesuaikannya dengan waktu yang telah ditentukan.

Tahap keenam, membuat kesimpulan. Pada tahap ini guru membimbing siswa dalam membuat kesimpulan berdasarkan hasil pengumpulan dan analisis data yang telah dilakukan. Pada tahap ini kemampuan literasi sains siswa yang didukung yaitu kemampuan menarik kesimpulan yang tepat.

\section{Kemampuan literasi sains siswa}

Kemampuan literasi sains siswa yang diteliti ada enam indikator, yaitu menerapkan pengetahuan yang sesuai, mengidentifikasi, membuat prediksi yang tepat, mengajukan hipotesis yang jelas, mengusulkan cara untuk menyelidiki pertanyaan ilmiah, dan menarik kesimpulan yang 
tepat. Hasil pencapaian kemampuan literasi sains siswa untuk setiap indikator dapat dilihat pada gambar 2.

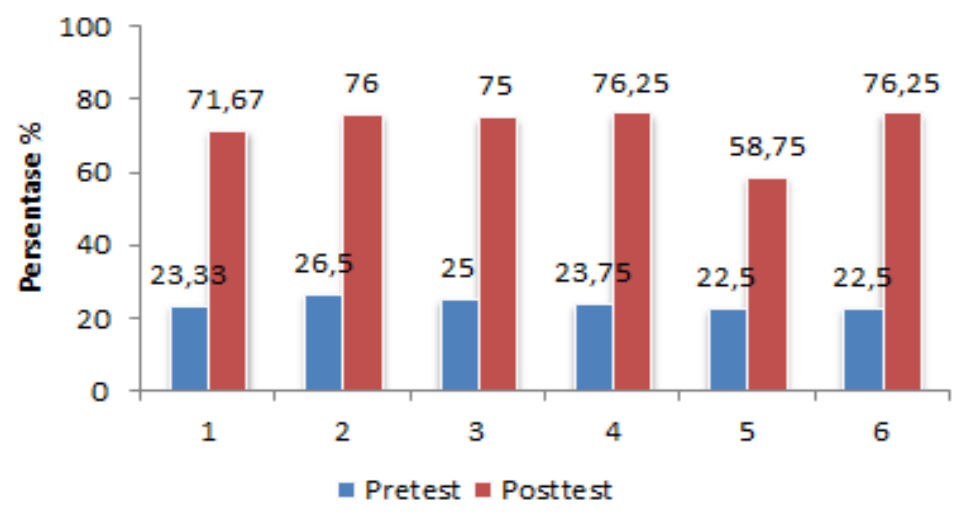

Gambar 2. Pencapaian setiap indikator literasi sains siswa

Indikator (1) menerapkan pengetahuan yang sesuai; (2) Mengidentifikasi; (3) membuat prediksi yang tepat; (3) mengajukan hipotesis yang jelas; (mengusulkan cara untuk menyelidiki pertanyaan ilmiah; (6) menarik kesimpulan yang tepat. Berdasarkan grafik pada gambar 2 terlihat bahwa dari keenam indikator yang diuji, persentase pencapain tertinggi pada posttest adalah pada indikator ke-4 dan ke-6, dan persentase pencapain terendah terdapat pada indikator ke-5. Kemudian berdasarkan gambar 2 dapat juga diperoleh informasi bahwasanya pencapaian yang diperoleh siswa mengalami peningkatan dapat dilihat dari pencapaian hasil pretest ke posttest setelah diterapkan model pembelajaran inkuiri terbimbing. Inkuiri adalah pendekatan dalam pembelajaran yang mendukung siswa untuk menemukan, menentukan dan menggunakan bermacam-macam sumber informasi dan ide untuk meningkatkan pemahaman mereka terhadap suatu topik, masalah, atau fenomena (V. D. I. Pratika dan Muchlis, 2016)

Pertama, menerapkan pengetahuan yang sesuai. Pada indikator ini contohnya siswa dituntut untuk menerapkan pengetahuan yang sesuai untuk menangani permasalahan asap industri yang mencemari udara. Kemampuan siswa dalam menerapkan pengetahuan yang sesuai diperoleh sebesar 71,67\% yang berada dalam kategori baik.

Kedua, mengidentifikasi. Pada indikator ini contohnya siswa dituntut untuk mengidentifikasi sifat koloid pada penghamburan cahaya matahari oleh partikel koloid di angkasa. Kemampuan siswa dalam mengidentifikasi diperoleh sebesar $76 \%$ yang berada dalam kategori baik.

Ketiga, membuat prediksi yang tepat. Pada indikator ini siswa dituntut untuk membuat prediksi yang tepat tentang susu yang dibiarkan berhari-hari. Kemampuan siswa dalam membuat prediksi yang tepat diperoleh sebesar $75 \%$ yang berada dalam kategori baik.

Keempat, mengajukan hipotesis yang jelas. Pada indikator ini contohnya siswa dituntut untuk mengajukan hipotesis yang jelas dari setetes cuka yang masuk ke dalam gelas yang berisi susu. Kemampuan siswa dalam mengajukan hipotesis yang jelas diperoleh sebesar 76,25\% yang berada dalam kategori baik.

Kelima, mengusulkan cara untuk menyelidiki pertanyaan ilmiah. Pada indikator ini contohnya siswa dituntut untuk mengusulkan cara dalam menyikapi permasalahan air sungai yang kotor/keruh sesuai dengan tema koloid. Kemampuan siswa dalam mengusulkan cara untuk menyelidiki pertanyaan ilmiah diperoleh sebesar 58,75\% yang berada dalam kategori cukup. Jika dilihat dengan indikator yang lain indikator ini merupakan indikator pencapaian terendah. Rendahnya pencapaian siswa pada indikator ini dapat disebabkan karena beberapa siswa masih 
mengalami kesulitan dalam mengerjakan soal-soal yang berkaitan dengan mengusulkan cara. Kesulitan yang dialami siswa dikarenakan siswa tidak terbiasa menyelesaikan soal-soal mengusulkan cara.

Keenam, menarik kesimpulan yang tepat. Pada indikator ini siswa dituntut untuk menarik kesimpulan yang tepat contohnya yaitu diberikan data hasil percobaan dari empat jenis campuran. Dari data yang disajikan siswa diminta untuk membuat suatu kesimpulan yang tepat apakah suatu campuran tersebut termasuk larutan, koloid atau suspensi. Kemampuan siswa dalam menarik kesimpulan yang tepat diperoleh sebesar $76,25 \%$ yang berada dalam kategori baik.

Persentase nilai rata-rata kemampuan literasi sains siswa berdasarkan hasil pretest dan posttest dapat dilihat pada gambar 3.

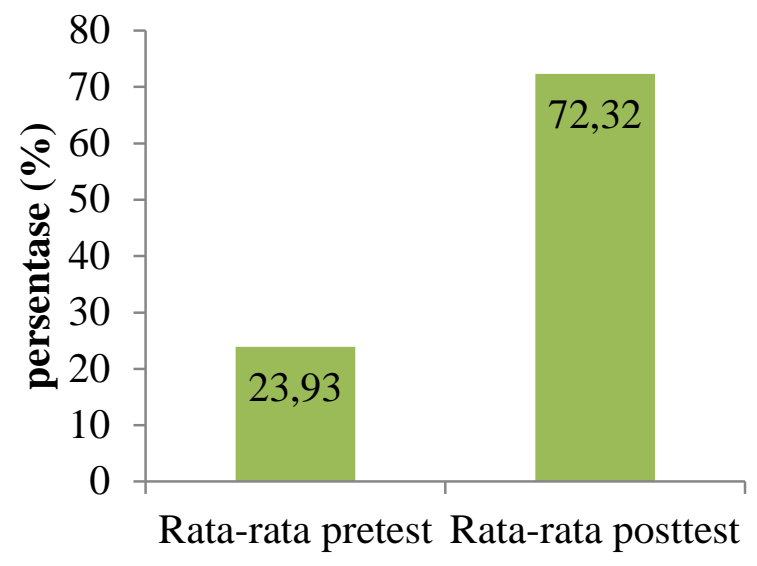

Gambar 3. Persentase nilai rata-rata kemampuan literasi sains siswa berdasarkan hasil pretest dan posttest

Berdasarkan gambar 3 rata-rata pretest diperoleh 23,93\% berada dalam kategori kurang baik dan rata-rata posttest diperoleh $72,32 \%$ berada dalam kategori baik. Dilihat dari hasil rata-rata pretest dan posttest siswa terdapat peningkatan kemampuan literasi sains siswa, hal ini menunjukkan bahwa inkuiri terbimbing dapat digunakan sebagai alternatif model pembelajaran untuk meningkatkan kemampuan literasi sains siswa. Dalam pembelajaran inkuiri siswa memiliki peluang untuk mencari dan menemukan sendiri pengetahuan yang dipelajarinya, dengan begitu siswa akan lebih mudah dalam memahami materi tanpa menghapal dan konsep yang ditemukan akan dapat lebih bertahan lama.

Dalam pembelajaran inkuiri siswa diajak untuk berfikir. Contohnya ketika siswa melakukan percobaan tentang sifat koloid, yaitu efek tyndall. Mereka mengamati jalannya sinar ketika campuran air dengan susu disinari dengan senter. Mereka mendapatkan hasil pengamatan bahwa campuran tersebut cahaya dihamburkan. Kemudian guru memberikan pertanyaan mengapa hal itu bisa terjadi, dengan pertanyaan yang diberikan maka siswa akan melakukan proses berpikir untuk menjawab pertanyaan tersebut. Dengan berpikir maka siswa akan mendapatkan pengalaman belajar yang bermakna. Pengalaman belajar yang didapatkan oleh siswa akan memberikan makna bagi kehidupan sehari-hari siswa nantinya.

Pembelajaran sains berbasis inkuiri memberi peluang kepada siswa untuk terus mengembangkan potensi diri secara optimal baik dari sisi kognitif, afektif maupun psikomotor dalam menemukan konsep-konsep sains (U. Toharudin, 2011). Pembelajaran inkuiri ini juga sejalan dengan pembelajaran berbasis konstruktivisme yang juga berpotensi untuk bisa mendorong munculnya berbagai keterampilan yang dibutuhkan untuk bisa menguasai kemampuan literasi sains. Pembelajaran yang dilakukan berbasis konstruktivisme memfasilitasi siswa untuk bisamembangun dan mengkonstruksikan pengetahuannya sendiri dalam hubungannya dengan dunia nyata (N. Wulandari, dan H. Sholihin, 2016) 


\section{SIMPULAN}

Berdasarkan hasil penelitian dan pembahasan penelitian, dapat disimpulkan sebagai berikut: Hasil pencapaian kemampuan literasi sains siswa untuk setiap indikator, yaitu menerapkan pengetahuan yang sesuai $71,67 \%$, mengidentifikasi $76 \%$, membuat prediksi yang tepat 75\%, mengajukan hipotesis yang jelas 76,25\%, mengusulkan cara untuk menyelidiki pertanyaan ilmiah $58,75 \%$, dan menarik kesimpulan yang tepat $76,25 \%$. Kemampuan literasi sains siswa melalui penerapan model pembelajaran inkuiri terbimbing pada materi sistem koloid siswa kelas XI MIPA SMA Negeri 5 Pekanbaru adalah 72,32\% dalam kategori baik.

\section{REFERENSI}

A. Rakhmawan, A. Setiabudi, dan A. Mudzakir. (2015). Perancangan Pembelajaran Literasi Sains Berbasis Inkuiri pada Kegiatan Laboratorium, Jurnal Penelitian dan Pembelajaran IPA, 1(1), 143-152

Azimi, A. Rusilowati, dan Sulhadi. (2017). Pengembangan Media Pembelajaran IPA Berbasis Literasi Sains untuk Siswa Sekolah Dasar, Pancasakti Science Education Journal, 2(2), 145-157

Chairisa, N., Sholahuddin, A., \& Leny, L. (2017). Perbedaan Literasi Ilmiah dan Hasil Belajar Pada Materi Sistem Koloid Antara Pembelajaran Yang Menggunakan Model Inkuiri Terbimbing Dengan Metode Eksperimen Riil Dan Eksperimen Animasi. Quantum: Jurnal Inovasi Pendidikan Sains, 7(2), 156-175.

Choerunnisa, R., Wardani, S., \& Sumarti, S. S. (2017). Keefektifan Pendekatan Contextual Teaching Learning dengan Model Pembelajaran Inkuiri Terhadap Literasi Sains. Jurnal Inovasi Pendidikan Kimia, 11(2).

Dian indah pratika, v. I. N. D. H. Y. (2016). Penerapan Model Pembelajaran Inkuiri Terbimbing Pada Materi Laju Reaksi Untuk Melatihkan Kemampuan Literasi Sains Siswa Kelas Xi Sman 1 Gondang Tulungagung. UNES A Journal of Chemical Education, 5(1). 9-18

El Islami, R. A. Z., Nahadi, N., \& Permanasari, A. (2016). Membangun Literasi Sains Siswa pada Konsep Asam Basa melalui Pembelajaran Inkuiri Terbimbing. Jurnal Penelitian dan Pembelajaran IPA, 2(2), 110-120

F. Huryah, R. Sumarmin, dan J. Effendi,. (2017). Analisis Capaian Literasi Sains Biologi Siswa SMA Kelas X Di Kota Padang, Jurnal Eksakta Pendidikan (JEP), 1(2), 72-79.

M. Fathurrohman. (2015). Model-model Pembelajaran Inovatif Alternatif Desain Pembelajaran yang Menyenangkan, Jogjakarta: Ar-Ruz Media

Mohamad Yafuz Bil Amri, Ani Rusilowati, dan Wiyanto. (2017) Penerapan Model Pembelajaran Conseptual Understanding Procedures untuk Meningkatkan Kemampuan Literasi Sains Siswa SMP Di Kabupaten Tegal, Unnes Physic Education Journal, 6(3),80-92

Novili, W. I., Utari, S., Saepuzaman, D., \& Karim, S. (2017). Penerapan Scientific Approach dalam Upaya Melatihkan Literasi Saintifik dalam Domain Kompetensi dan Domain Pengetahuan Siswa SMP pada Topik Kalor. Jurnal Penelitian Pembelajaran Fisika, 8(1), 57-63

Riduwan. (2010). Rumus dan Data dalam Aplikasi Statistika, Bandung: Alfabeta

Rohmi, P. (2017). Peningkatan Domain Kompetensi dan Pengetahuan Siswa melalui Penerapan Levels Of Inquiry dalam Pembelajaran IPA Terpadu. Edusains UIN Syarif Hidayatullah, 9(1).

Sugiyono. (2017). Metode Penelilitian Kuantitatif, Kualitatif, dan RひD, Bandung: Alfabeta,

Suharsimi Arikunto. (2009). Manajemen Penelitian, Jakarta: Rineka Cipta 
U. Toharudin. (2011). Membangun Literasi Sains peserta Didik, Bandung: Humaniora

W. Sanjaya. (2007). Strategi Pembelajaran Berorientasi Standar Proses Pendidikan, Jakarta: Kencana

Wulandari, N. (2016). Analisis kemampuan literasi sains pada aspek pengetahuan dan kompetensi sains siswa smp pada materi kalor. Edusains, 8(1), 66-73.

Yuliati, Y. (2017). Literasi Sains dalam Pembelajaran IPA. Jurnal Cakrawala Pendas, 3(2), 21-28 